\title{
PENERAPAN PEMANTAUAN PROSES HUKUM PIDANA BERBASIS ANDROID
}

\author{
Aldo Andy Yoseph Tama Marpaung, Irfan Saputra Tampubolon, Miando Mangara Situkkir, \\ Brando Benedictus Simarmarta, Delima Sitanggang, Evta Indra \\ Program Studi Sistem Informasi Fakultas Teknologi dan Ilmu Komputer Universitas Prima Indonesia \\ Medan, Sumatera Utara, Indonesia \\ Email: mery.silitonga1974@gmail.com
}

\begin{abstract}
ABSTRAK- Tujuan utama hukum adalah untuk mewujudkan ketertiban. Dalam melakukan tugas penanganan narapidana yang terkena sanksi hukum akan sangat berlangsur lama dalam melaksanakan pidana. Maka dari itu, Tujuan dari penelitian ini adalah Membuat sebuah Aplikasi yang dimana dapat mempermudah mengetahui tentang narapidana yang terkena hukuman
\end{abstract}

Kata kunci : Hukum, Android, Masyarakat, Kejaksaan.

\section{PENDAHULUAN}

Hukum merupakan suatu sistem yang dapat berperan dengan baik dan tidak pasif dimana hukum mampu dipakai di tengah masyarakat, jika instrumen pelaksanaanya dilengkapi dengan kewenangankewenangan dalam bidang penegakan hukum. Sehubungan dengan hal tersebut, L.M Friedman, menyebutkan bahwa: Pada hakikatnya eksistensi kejaksaan dalam proses penegakan hukum di Indonesia adalah untuk mencapai tujuan hukum, yakni kepastian hukum, keadilan, dan kemanfaatan hukum bagi pencari keadilan. "Hukum tersn dari sub sistem hukum yang berupa substansi hukum, struktur hukum, dan budaya hukum. Unsur sistem hukum ini sangat menentukan apakah suatu sistem hukum dapat berjalan dengan baik atau tidak. Substansi hukum menyangkut segala aspek-aspek pengaturan hukum atau perundang-undangan, struktur hukum lebih menekankan kepada kinerja aparatur hukum serta sarana dan prasarana hukum itu sendiri, sementara budaya hukum menyangkut perilaku masyrakatnya." Hal tersebut sejalan dengan yang disebutkan oleh Mochtar Kmaatmadja mengenai tujuan hukum dimana menurutnya bahwa: "Tujuan utama hukum adalah untuk mewujudkan ketertiban (order).

Tujuan ini sejalan dengan fungsi utama hukum yang mengatur. Ketertiban merupakan syarat mendasar yang sangat dibutuhkan oleh (L.M. Friedman, The Legal System; A Social Science Persfective, (New York, Russel Sage Foundation,1975), hal. 11. Marwan Effendy., kejaksaan Republik Indonesia, Posisi dan Fungsinya dari Perspektif Hukum, (Jakarta: PT. Gramedia Pustaka Utama, 2005), hal. 151. Mochtar Kmaatmadja., Fungsi dan Perkembangan Hukum Dalam Pembangunan Nasional, (Bandung: Bina Cipta, Tanpa Tahun), hal. 2-3.) masyarakat. Ketertiban benar-benar merupakan kebutuhan masyarakat manusia yang nyata dan objektif. "Sementara itu, para penganut paradigma hukum alam berpendapat bahwa tujuan hukum adalah untuk mewujudkan "keadilan". Dalam perkembangan dan kenyataanya, keadilan bukan satu-satunya istilah yang digunakan untuk menujukkan tujuan hukum. Dalam suatu negara hukum modern (welfare state) tujuan hukum adalah untuk mewujudkan "Kesejahteraan". Berkenaan dengan tujuan hukum, Mochtar Kmaatmadja juga menyebutkan bahwa tujuan pokok dan pertama dari hukum adalah ketertiban. Di samping itu, tujuan lain dari hukum adalah tercapainya keadilan yang berbeda-beda isi dan ukurannya menurut masyarakat yang dijelmakan olehnya, manusia tidak mungkin mengembangkan bakat-bakat dan kemampuan yang diberikan Tuhan kepadanya secara optimal di lingkungan masyarakat tempat ia hidup. Tujuan hukum menuru B. Arief Sidharta, Dalam pengertian lain, tujuan hukum tersebut, ditempatkan ke dalam ajaran hukum sebagai pandangan legalisme (logische geschlossenheit) yang menitikberatkan pada keadilan, pandangan fungsionil (functionele rechstleer) merupakan cita hukum bangsa indonesia yang berakar dalam Pancasila, yang dinyatakan dalam alinea IV Pembukaan Undang-Undang Dasar 1945 yang menjadi landasan falsafah dalam menata kerangka dan struktur dasar organisasi negara.

\section{ISI PENELITIAN}

Metode yang digunakan dalam Penelitian ini yaitu 1) Data Perkara terdapat data kasus pidana yang ada. 2) Penahanan yang akan dilakukan untuk menempatkan terdakwa di tempat tertentu oleh penyidik. 3) Barang Bukti hasil dari suatu delik yang dilakukan. 4) Surat Perintah JPU (P.16A) kepada jaksa yang menangani. 5) Pelimpahan Berkas yang dikirim oleh penyelidik kepada kepala kejaksaan negeri. 6) Hasil Putusan Pengadilan dari pihak kejaksaan negara yang berguna sebagai sarana pemerintah yang menjadi penuntut umum pada suatu perkara pidana kepada yang melakukan pelanggaran hukum. 6b) Upaya Hukum penuntut umum untuk tidak menerima putusan pengadilan yang berupa perlawanan atau banding untuk mengajukan permohonan peninjauan kembali dalam hal serta menurut cara yang diatur dalam undang-undang ini. 
7) Eksekusi narapidana yang menerima putusan pengadilan yang sudah berkekuatan penuh.

\section{A. Analisis Sistem}

Analisis ini bertujuan untuk mengidentifikasi permasalahan-permasalahan yang ada pada sistem serta menentukan kebutuhan dari sistem yang dibangun. Aplikasi yang dibuat merupakan program untuk mencari data informasi narapidana berbasis android. Pada penerapan sistem aplikasi ini, akan mempermudah masyarakat untuk mengetahui data identitas narapidana dari sebuah perkara menggunakan aplikasi yang sudah berbasis android. Dengan menggunakan aplikasi yang dibuat, masyarakat dapat melihat riwayat data dari aplikasi menggunakan internet tanpa datang ke pengadilan negeri.

\section{B. Prosedur Sistem Usulan}

Berdasarkan data yang sudah dikumpulkan oleh Kejaksaan atau Penyidik terhadap terdakwa atau narapidana. Bahwasanya sudah dapat dipastikan eksekusinya, surat keputusan yang dijatuhkan kepada terdakwa karena sudah melanggar undangundang dasar yang ditetapkan dan dijatuhkannya hukuman. Maka, terdapat sebuah hasil tahapan dari penelitian ini. Adapun tahapan tersebut dapat dilihat pada gambar berikut;

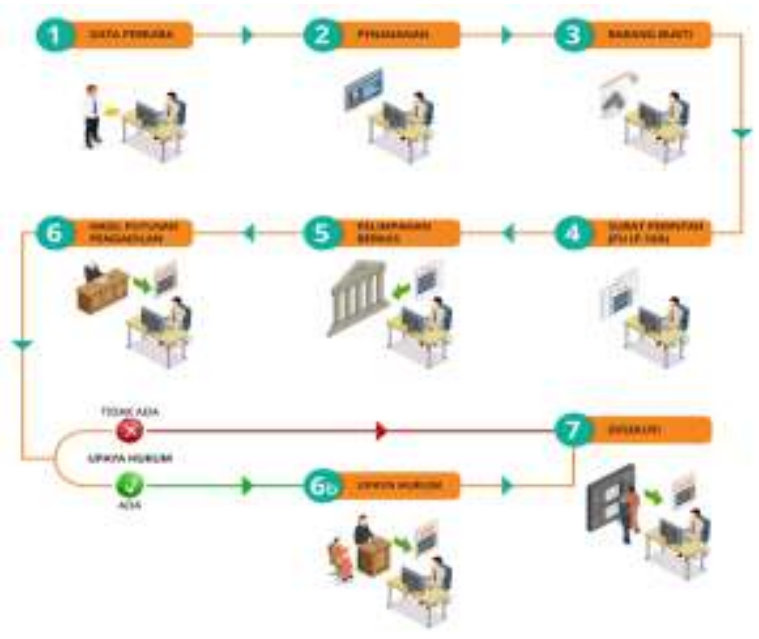

Gambar 3.1 Tahapan Proses Sebuah Perkara Adapun penjelasan dari tahapannya sebagai berikut:

1. Operator menginput Data Perkara baru berisi informasi pada aplikasi berupa: no.perkara, jenis pidana, asal berkas perkara, maupun data tersangka.

2. Operator menginput masa penahan tersangka, baik dipihak penyidik maupun kejaksaan.

3. Operator menginput data barang bukti.

4. Operator membuat surat perintah JPU (P.16A) beserta data jaksa penuntut umum yang bertugas menangani perkara tersebut.
5. Operator membuat surat pengantar pelimpahan berkas ke pengadilan negeri, kemudian menginput data hakim yang diberikan oleh pengadilan negeri.

6. Operator menginput data hasil putusan pengadilan, serta memeriksa apakah ada upaya hukum yang diajukan oleh terpidana atas putusan pengadilan.

6b. Jika terdapat upaya hukum dari terdakwa maka operator memasukkan data upaya hukum yang dilakukan oleh terpidana atas hukuman pengadilan.

7. Jika tidak ada upaya hukum, maka tahapan dari point $6 \mathrm{~b}$ dengan tahapan point 7 sama dengan cara operator memasukkan data eksekusi atas putusan pengadilan terhadap terpidana maupun barang bukti, serta data lain yang terkait eksekusi.

\section{Desain Sistem}

\section{Use Case Diagram}

Use Case Diagram adalah diagram model UML ( Unified Modeling Language ) yang digunakan untuk menggambarkan persetujuan fungsional yang diharapkan dari suatu sistem. Use case diagram menjelaskan peran admin dalam mengakses data.

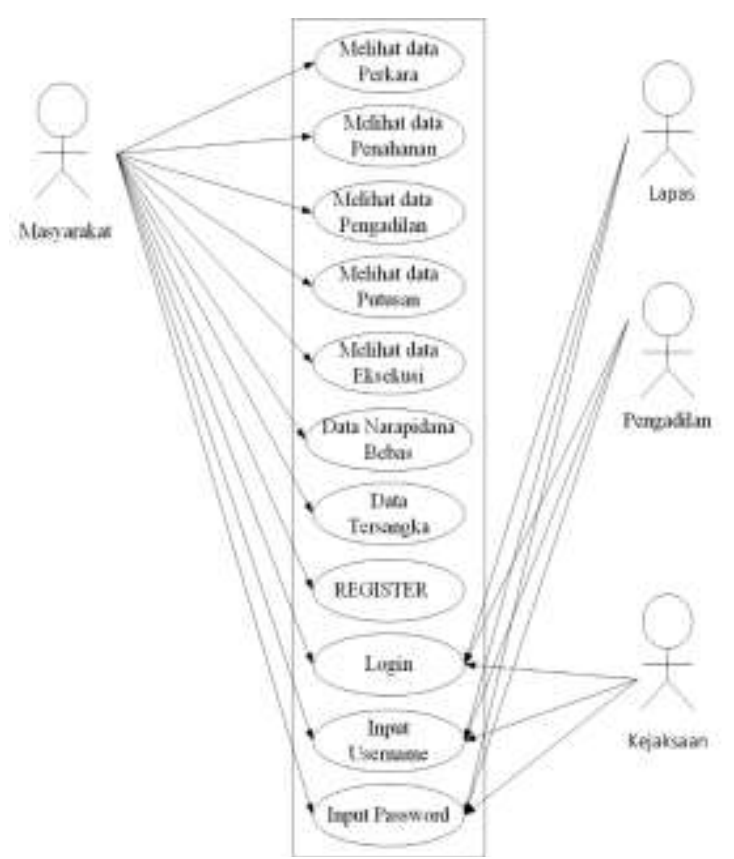

Gambar 3.2 Use Case Diagram

\section{Activity Diagram}

Activity diagram menjelaskan langkah-langkah cara kerja dalam sistem yang dirancang, sehingga setiap alur kerja dimulai dari awal, kondisi yang dapat terjadi selama eksekusi program hingga akhir sistem berjalan. 


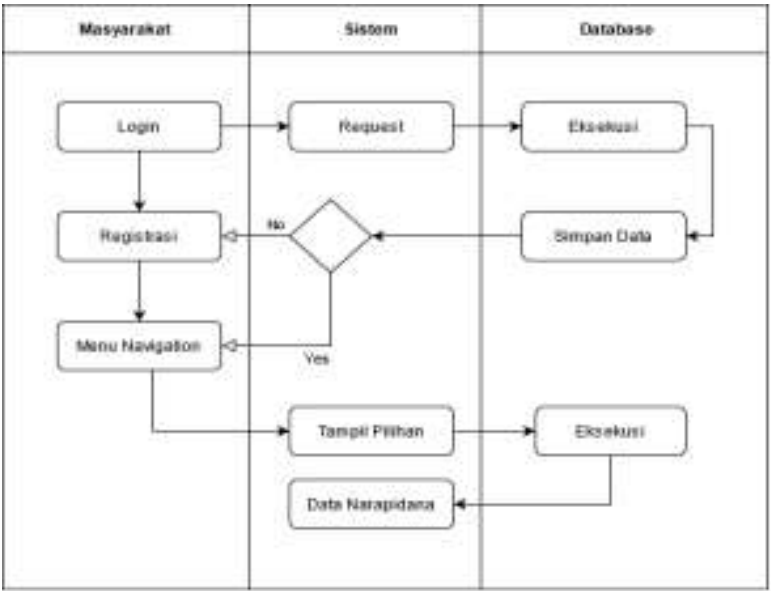

Gambar 3.3 Activity Diagram

Hasil dan Pembahasan

Pada hasil penelitian ini dibangun sebuah sistem untuk mencari data informasi narapidana berbasis android. Sistem ini berfungsi mempermudah masyarakat untuk mengetahui data identitas narapidana dari sebuah perkara menggunakan aplikasi yang sudah berbasis android. Dengan menggunakan aplikasi yang dibuat, masyarakat dapat melihat riwayat data dari aplikasi tersebut menggunakan internet tanpa harus datang ke pengadilan negeri. Berikut ini merupakan gambaran tampilan interface mengenai sistem perencanaan pengolaan data narapidana.

\section{Tampilan Menu Utama}

Gambaran dibawah merupakan halaman utama sistem yang berisikan tampilan menu utama, User dapat memilih untuk login dengan mengklik menu Masyarakat, Lapas, Pengadilan atau Kejaksaan sesuai dengan otoritas.

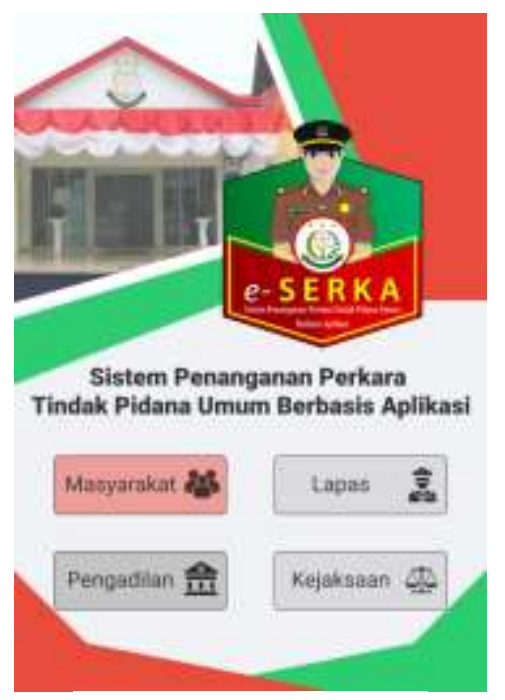

Gambar 3.4 Menu Utama

\section{Tampilan Menu Login}

Merupakan halaman utama sistem yang berisikan tampilan login user dengan menggunakan username dan password atau user dapat mendaftar jika belum mempunyai akun SERKA.

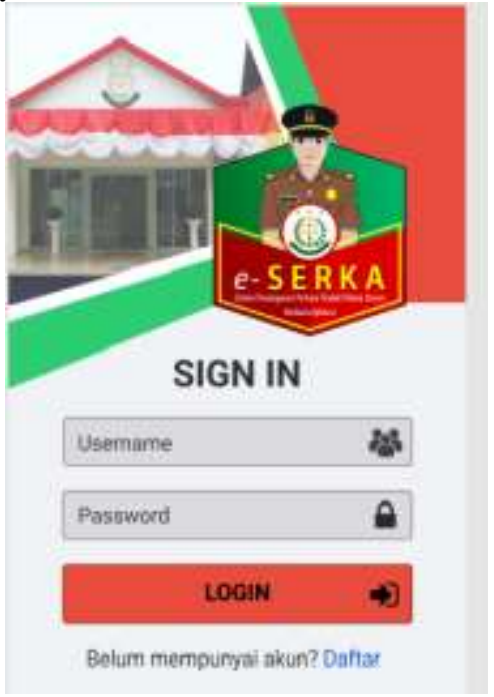

Gambar 3.5 Tampilan Menu Login

3. Tampilan Menu Registrasi

Merupakan tampilan menu registrasi, user dapat memasukkan data diri untuk registrasi akun SERKA.

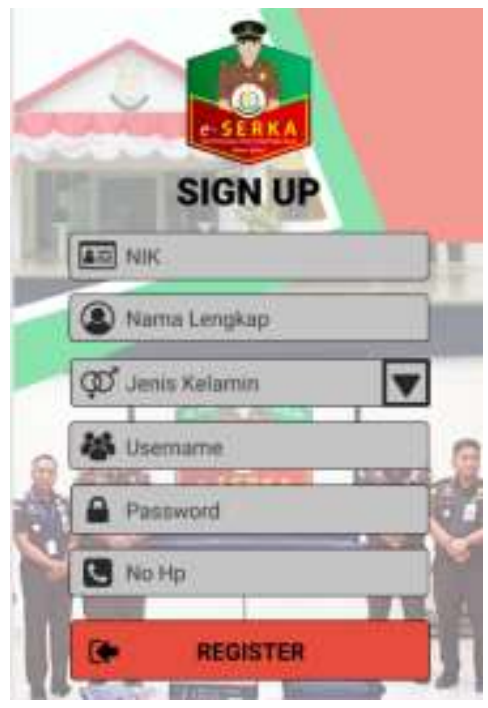

Gambar 3.6 Tampilan Menu Registrasi

\section{Tampilan Menu Navigasi}

Pada tampilan menu navigasi, user dapat memilih menu home untuk menuju tahapan pilihan perkara. 
JUSIKOM PRIMA (Jurnal Sistem Informasi dan Ilmu Komputer Prima)

Vol. 5 No. 1, Agustus 2021

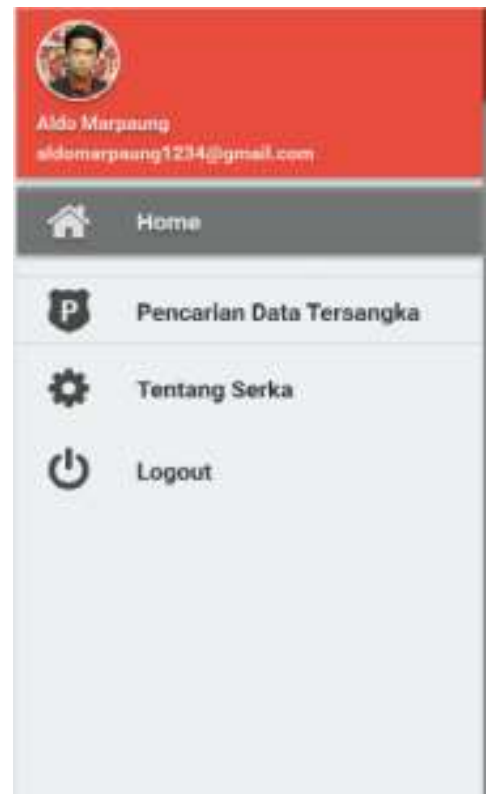

Gambar 3.7 Tampilan Menu Navigasi

\section{Tampilan Menu Home}

User dapat melanjutkan menu pilihan dengan mengklik logo SERKA.

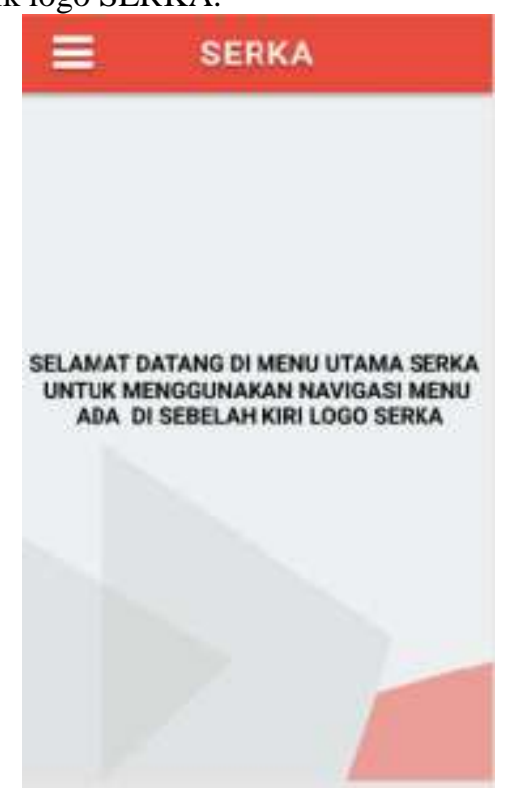

Gambar 3.8 Tampilan Menu Home

\section{Tampilan Menu Pilihan}

User dapat memilih salah satu opsi data mengenai narapidana.

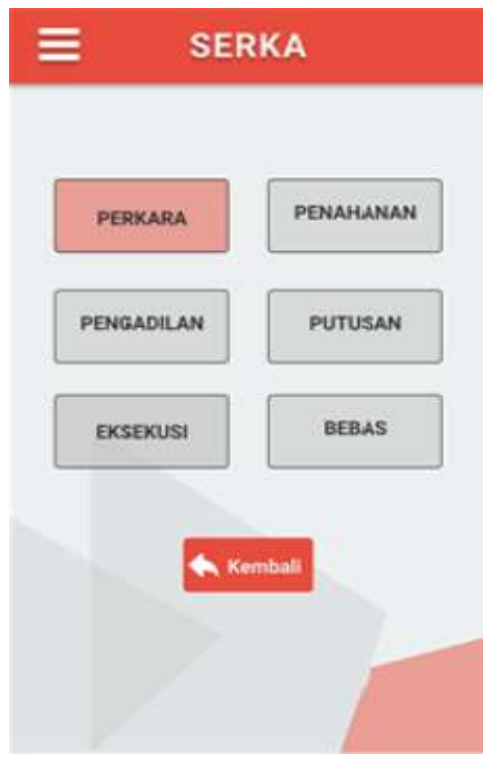

Gambar 3.9 Tampilan Menu Pilihan

7. Tampilan Menu Data Perkara

Pada tampilan ini User dapat mencari nama narapidana dan mengklik view detail.

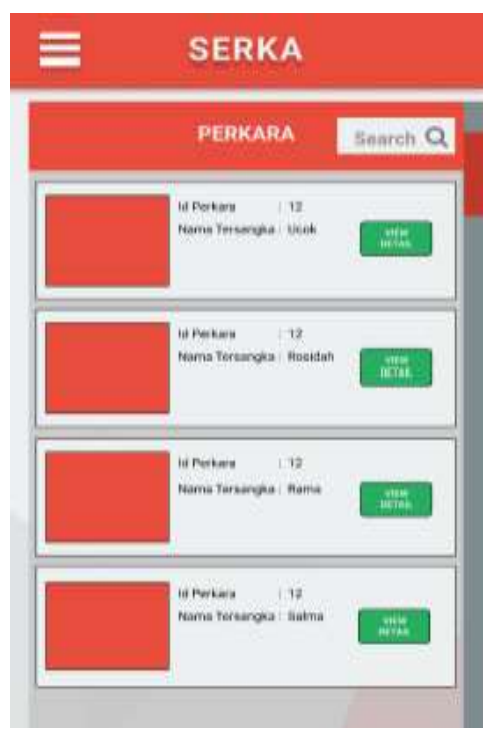

Gambar 3.10 Tampilan Menu Data Perkara

8. Tampilan Menu Data Narapidana

Pada tampilan ini user dapat mengetahui data narapidana menurut perkara. 


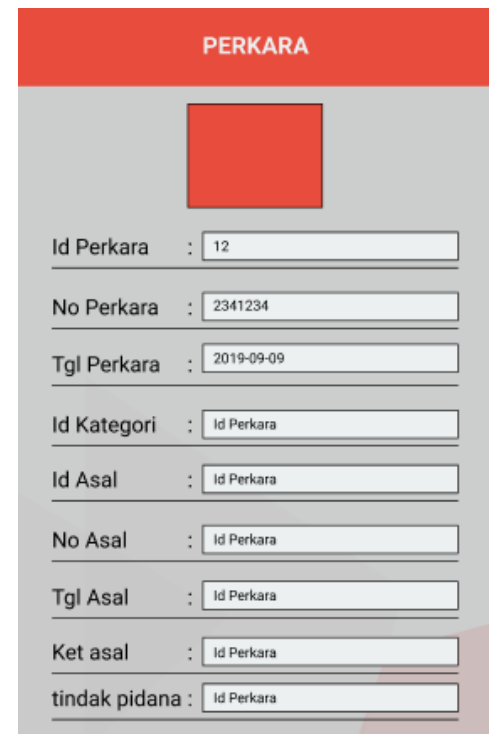

Gambar 3.11 Tampilan Menu Data Narapidana

\section{KESIMPULAN}

Seperti yang telah terjadi saat ini pada dasarnya semua hukum bertujuan untuk menciptakan suatu keadaan dalam kehidup masyarakat, baik dalam lingkungan yang kecil maupun dalam lingkungan yang lebih besar, agar didalamnya terdapat suatu keserasian, suatu ketertiban, suatu kepastian hukum dan lain sebagainya. Untuk menjamin adanya kepastian hukum, peraturan-peraturan terkait masalah pidana telah dituangkan dalam Kitab Undangundang Hukum Pidana (KUHP) yang saat ini masih menjadi ketentuan pokok dari hukum pidana Indonesia.

Seiring dengan perkembangan jaman, dan semakin berkembangnya teknologi hukum berkembang mengkuti setiap kebutuhan manusia. Hukum terus mengalami perubahan guna perbaikanperbaikan di segala segi kehidupan manusia demi terwujudnya tujuan nasional. Tak terkecuali di dalam sistem kepenjaraan di Indonesia. Sistem kepenjaraan telah mengalami perubahan karena di anggap tidak sesuai dengan sistem pemasyarakatan berdasarkan Pancasila dan Undang-Undang Dasar 1945. Sistem kepenjaraan hanya mengutamakan unsur balas dendam dan pengenaan nestapa sehingga hak asasi narapidana tidak diindahkan.
Maka dibangun sebuah sistem untuk mencari data informasi narapidana berbasis android. Sistem ini berfungsi mempermudah masyarakat untuk mengetahui data identitas narapidana dari sebuah perkara menggunakan aplikasi yang sudah berbasis android.

Metode yang digunakan dalam Penelitian ini yaitu Data Perkara, Penahanan, Barang Bukti, Surat Perintah JPU (P.16A), Pelimpahan Berkas, Hasil Putusan Pengadilan, Upaya Hukum, Eksekusi.

\section{PENUTUP}

Dengan menerapkan sebuah sistem untuk mencari data informasi narapidana berbasis android. pengguna tidak perlu datang ke kantor pengadilan negeri atau kelapas untuk mengetahui informasi data dari terpidana. Dengan menggunakan aplikasi ini, masyarakat dapat melihat riwayat data terpidana.

\section{DAFTAR PUSTAKA}

[1] Undang-Undang Nomor 11 tahun 2019 tentang Sistem Nasional Ilmu Pengetahuan dan Teknologi

[2] Jusuf Kalla, 2015 'Landasan Hukum Inovasi Kota Cerdas'.

[3] Ilman Hadi, 2012, 'Peran Jaksa dalam Proses Hukum Perdata dan Pidana'.

[4] Agus Hernowo, 2017. Peran Masyarakat Dalam Negara Hukum

[5] Sovia Hasanah, 2017, Penggolongan Penempatan Narapidana dalam Satu Sel LAPAS.

[6] Tri Jata Ayu Pramesti, 2013, Tempat Kejadian Perkara, Daerah Hukum Polisi, dan Kewenangan Relatif Pengadilan

[7] Chazawi dan Adami, 2002, Pelajaran Hukum Pidana-I, PT. Raja Grafindo Persada, Jakarta

[8] Muljono Wahju. 2012. Pengantar Teori Kriminologi. Yogyakarta: Pustaka Yustisia

[9] Dino Riska Afdhali, 2015, Peran Jaksa Dalam Penyelesaian Tindak Pidana Korupsi (Studi di Kejaksaan Negeri Mataram)

[10] Syahrin, M.A. et al., 2018.Legal Impacts of The Existence of Refugees and Asylum Seekers in Indonesia. International Journal of Engineering and Technology, 9(5), pp.10511058.

[11] Ali, Ahmad. 2012. Menjelajahi Kajian Empiris Terhadap Hukum, Jakarta: Karisma Putra Utama 